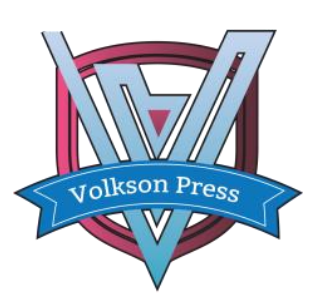

Contents List available at VOLKSON PRESS

Economics \& Management Innovations(EMI)

DOI : http://doi.org/10.26480/icemi.01.2017.74.76

\title{
The Evolution and Enlightenment of Business Method Patent Eligibility in the United States
}

\section{Yijie Wu}

${ }^{1}$ Wuhan University of Technology, 122 Luo Shi Road, Hong Shan District, Wuhan, Hubei Province, China

*E-mail:wu@whut.edu.cn

This is an open access article distributed under the Creative Commons Attribution License, which permits unrestricted use, distribution, and reproduction in any medium, provided the original work is properly cited.

\section{ARTICLE DETAILS}

\section{Article History:}

Received 02 october 2017 Accepted 06 october 2017 Available online 11 october 2017

\section{Keywords:}

patentable subject matter; method patent; software patent; intellectual property

\section{ABSTRACT}

The Patent Eligibility of method in the United States has experienced from the stages of strong exclusionary to increasing protection, and then stepped into a period of limited protection after Mayo v. Prometheus. But it seems that the decision in Enfish LLC v. Microsoft Corp has brought a ray of hope to business method inventions. Amended Patent Examination Guidelines came into force in China on April 2017 that look set to make it easier to obtain patent protection on certain method and software invention, but also means there will be new challenges.Under this background, we are supposed to improve the patent system and policy directed by realistic interests and based upon the current development in a flexible way.

\section{Introduction}

The word of "Patentable subject matter" is come from patent law of the United States, which refers to the inventions that the patent law grant patent right under section 101 of title 35 the U.S. Code. With regard to business methods inventions, the Courts and the USPTO(United States Patent and Trademark Office)would determine the limits and bounds of patent eligible. And these years, U.S. patent laws and judicial system have been trying to keep up with the pace of evolving technological innovation being protected by or sought to be protected by U.S. Patents.

This paper will discuss some important Supreme Court decisions in the United States starting with Hotel. The main body consists of two chapters. The first chapter analyses the evolution of method patent eligibility in the United States. The second chapter clarifies the state and enlightenments of of China's method patent eligibility.

\section{Evolution of Method Patent Eligibility in the United States}

As shown by a comprehensive survey of the patent history in the United States, the patent eligibility of methods has experienced from the stages of strong exclusionary to increasing protection, and then stepped into a period of limited protection after Mayo v. Prometheus. However, it seems Enfish LLC v. Microsoft Corp decision has brought a ray of hope to methods implemented inventions.

Table1 Evolution of Patent Eligibility of Methods in the United

\begin{tabular}{|c|c|c|c|}
\hline \multicolumn{4}{|c|}{ States } \\
\hline Stages & Cases & $\begin{array}{c}\text { Decis } \\
\text { ion }\end{array}$ & Significance \\
\hline \multirow{4}{*}{$\begin{array}{c}\text { strong } \\
\text { exclusio } \\
\text { nary }\end{array}$} & $\begin{array}{l}\text { Hotel security } \\
\text { checking } \\
\text { co.v . lorraine co. } \\
\text { in } 1908 \\
\end{array}$ & $\begin{array}{c}\text { Invali } \\
\quad \mathrm{d}\end{array}$ & $\begin{array}{l}\text { Form the"business method } \\
\text { exception"rule }\end{array}$ \\
\hline & $\begin{array}{c}\text { Gottschalk v. } \\
\text { Benson in } 1972\end{array}$ & $\begin{array}{c}\text { Invali } \\
\mathrm{d}\end{array}$ & $\begin{array}{l}\text { Obey the "business method } \\
\text { exception"rule }\end{array}$ \\
\hline & $\begin{array}{c}\text { Dann v. Johnston } \\
\text { in } 1976 \\
\end{array}$ & $\begin{array}{c}\text { Invali } \\
\mathrm{d}\end{array}$ & \multirow{2}{*}{$\begin{array}{l}\text { Reaffirms the principle, of th } \\
\text { three recognized judicial } \\
\text { exceptions to§101-laws of } \\
\text { nature, natural phenomena, } \\
\text { and abstract ideas }\end{array}$} \\
\hline & $\begin{array}{l}\text { Parker v. Flook in } \\
1978\end{array}$ & $\begin{array}{c}\text { Invali } \\
\mathrm{d}\end{array}$ & \\
\hline
\end{tabular}

\begin{tabular}{|c|c|c|c|}
\hline \multirow{5}{*}{$\begin{array}{l}\text { increasi } \\
\text { ng } \\
\text { protecti } \\
\text { on }\end{array}$} & $\begin{array}{c}\text { Freeman in } \\
1978 ; \\
\text { Walter in } 1980 ; \\
\text { Abele in } 1982 \\
\end{array}$ & $\begin{array}{l}\text { Valid } \\
\text { Invali } \\
\quad \mathrm{d} \\
\text { valid }\end{array}$ & Form the F-W-A test \\
\hline & Con Table1 & & \\
\hline & $\begin{array}{l}\text { Diamond v. Diehr } \\
\text { in } 1981\end{array}$ & valid & $\begin{array}{c}\text { If an abstract business } \\
\text { method results in a physical } \\
\text { transformation of an article or } \\
\text { is tied to a tangible machine, } \\
\text { it should be a patent-eligible } \\
\text { subject matter }\end{array}$ \\
\hline & $\begin{array}{l}\text { In re Alappat in } \\
1994\end{array}$ & valid & Abandoning the F-W-A Test \\
\hline & $\begin{array}{c}\text { State Street Bank } \\
\text { v. Signature } \\
\text { Financial in } 1998 \\
\end{array}$ & valid & $\begin{array}{l}\text { Open a floodgate of software } \\
\text { and business-method patent } \\
\text { applications }\end{array}$ \\
\hline \multirow{3}{*}{$\begin{array}{l}\text { limited } \\
\text { protecti } \\
\text { on }\end{array}$} & $\begin{array}{l}\text { In re Bilski in } \\
2010\end{array}$ & $\begin{array}{c}\text { Invali } \\
\mathrm{d}\end{array}$ & $\begin{array}{c}\text { Adopted "machine-or- } \\
\text { transformation" test }\end{array}$ \\
\hline & $\begin{array}{c}\text { Mayo v. } \\
\text { Prometheus in } \\
2012 \\
\end{array}$ & $\begin{array}{c}\text { Invali } \\
\mathrm{d}\end{array}$ & $\begin{array}{c}\text { Denied that the "machine or } \\
\text { transformation test" is the } \\
\text { only standard }\end{array}$ \\
\hline & $\begin{array}{l}\text { Alice Crop. v. CLS } \\
\text { Bank in } 2014\end{array}$ & $\begin{array}{c}\text { Invali } \\
\mathrm{d}\end{array}$ & Form Mayo two step test \\
\hline \multirow{3}{*}{$\begin{array}{l}\text { new } \\
\text { cases }\end{array}$} & $\begin{array}{c}\text { Enfish LLC v. } \\
\text { Microsoft } \\
\text { Corporation } \\
\text { Fed.Cir. In } 2016 \\
\end{array}$ & valid & \multirow{3}{*}{$\begin{array}{l}\text { Emphasize patent functions } \\
\text { to innovation }\end{array}$} \\
\hline & $\begin{array}{c}\text { Mcro. Inc v. } \\
\text { Bandal Namco } \\
\text { Games America } \\
\text { inc in } 2016 \\
\end{array}$ & valid & \\
\hline & $\begin{array}{l}\text { Apple v. Mirror } \\
\text { World in } 2016\end{array}$ & valid & \\
\hline
\end{tabular}

\subsection{The Era of "Business Method Exception"}

The purely methods were basically excluded from the "patentable subject matter" since the patent law was implemented in the US in 1790. And in Hotel security checking $v$. lorraine in 1908, the"business method exception"rule was formed. In Gottschalk vs. Benson, the Supreme Court 
ruled that a process claim directed to a numerical algorithm, was not patentable because "the patent would wholly pre-empt the mathematical formula and in practical effect would be a patent on the algorithm itself." The ruling stated "Direct attempts to patent programs have been rejected [and] indirect attempts to obtain patents and avoid the rejection ... have confused the issue further and should not be permitted." [i] What's more, in Dann v. Johnston case, Parker vs. Flook case, the Supreme Court reaffirms the rule.

In 1980's, U.S.government implemented the "pro-patent policy", consist of establishment of CAFC(the Court of Appeals of the Federal Circuit), the reform of USPTO, the extension of patent and so on ${ }^{[i]}$. Therefore in the case of Diamond v.Chakrabarty in1980, the Supreme Court supported the granting of patents for "microbial organisms manufactured by means of genetic recombination techniques, artificially manufactured."[iii] And in Diamond vs. Diehr, the Supreme Court concluded that it should be vaild if an abstract business method results in a physical transformation of an article or is tied to a tangible machine. ${ }^{[i v]}$ Then the "Freeman-WalterAbele" (F-W-A) Test was founded in In re Freeman, In re Walter and In re Abele. After 1990s, the US has entered the new historic era of patent protection,which even gradually extended to biological microorganisms, plants, animals. In In re Alappat, court changed course by abandoning the F-W-A Test. The decision of State Street Bank v. Signature in 1998 formed an important mid-to-late-1990s trilogy of Federal Circuit opinions because it confirmed business method patent in practice. The result was to open a floodgate of software and business-method patent applications. [v] $^{\text {[v }}$

\subsection{Limited Protection Since Mayo v. Prometheus}

The excessive expansion of the patent policy has brought many problems, for example, raise a lot of patent disputes and "patent troll" [vi]. So the Supreme Court tried to shrink the scope of the patentable subject matter. In 2008, CAFC adopted "machine-or-transformation" test in In re Bilski case and explained that a claim shall be tied to specific machines or transferred into other different things. However, the Supreme Court denied the "machine or transformation test" is the only standard[vii].

In addition, In 2004 Prometheus sued Mayo for infringement and in 2008 the district court held the patents invalid under§101.The debate between the two companies was based on a certain diagnostic test, specifically concerning the use of thiopurine drugs, used to treat autoimmune diseases. The controversy focus on whether (1) they only claimed natural phenomena, and (2) the machine-or-transformation test can determine a process is patentable subject matter[viii].On March 28, 2008 the district court granted summary judgment in favor of Mayo and held the patents invalid. On appeal by Prometheus the Federal Circuit reversed and upheld the methods claims as valid under the machine-or-transformation test. At last, the Federal Supreme Court's March 20, 2012 decision invalidates patent claims when they invoke a law of nature but do not "confine their reach to particular applications of those laws." This case marks a challenge to draft patent claims for any industry interested in application of a law of nature, or even an algorithm ${ }^{[i x]}$. The impact of this case may extend from medical arts to electrical technologies, business methods, and other technologies.

\subsection{Enfish: a Ray of Hope to Business Methods}

The patents in Alice Corp. v. CLS Bank International were test by "Mayo two steps"and held to be invalid because the claims were drawn to an abstract idea, and implementing those claims on a computer was not enough to transform that idea into patentable subject matter. Although the Alice opinion did not mention software as such, the case was widely considered as a decision on software patents or patents on software for business methods ${ }^{[x]}$. Since the Alice decision and through 08-JUN-2016, about $66 \%$ of 559 patents subject to Federal Court decisions have been invalidated on patentability issues..[xi]

However In Enfish, LLC v. Microsoft Corporation in 2016. the patents at issue described and claimed the use of a "self-referential" table in a database. The patents also explained how the use of self-referential tables provides several benefits over conventional tables, such as "faster searching of data," "more effective storage" and "more flexibility in configuring the database."[xii] Under the first step of the analysis, the district court determined that the asserted claims were directed to an abstract idea: "storing, organizing, and retrieving memory in a logical table" or simply "the concept of organizing information using tabular forms." The district court ultimately determined that the claims at issue failed to recite patent-eligible subject matter under Alice v. CLS Bank. The Federal Circuit reversed, and in doing so interpreted the Supreme Court's test in a way that could save a significant number of inventions from failing

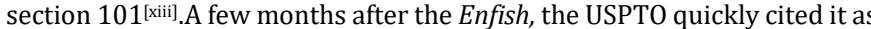
a guideline and the core of decisions, of Bascom, Mcro and Mirror, is the patent functions to innovation rather than entirely negating the method and software invention.

\section{The Enlightenment of Method Patent Eligibility}

It seems that the new Patent Examination Guidelines open a window for business method, though business method is still not eligible for patent under the revised Guidelines.

\subsection{The State of Method Patent Eligibility in China}

The State Intellectual Property Office of China just published a set of proposed amendments to its Patent Examination Guidelines in April 2017, covering the important aspects of the patent eligibility of software and business models. An invention related to business method is usually implemented by software in practice, and viewed to include technical features.

\subsection{Suggestion to Patent Policies in China}

The protection of software and business models would also bring China many challenges. First being intangible product, method patent application and examination are more difficult than physical product, we should increase the written requirements of patent claims to ensure the quality. To a certain extent, it means companies may face a higher risk of patent suits, which could discourage innovation and restrain growth. Last, it will also influence patent market because of the price increasing in the patent licensing fees or transfer fee, along with the cost of products.

To sum up, being aimed at the challenges as well as the problems in the implementation process of patent applications, examination and protection issues, there are three points to help, (1)improve patent quality. China is now the first highest-ranking country for patent applications, but China needs to do more to improve patent quality. Reinforcing examination standards, give the specific guidelines may help native applicants write high class applications in the drafting of patent. (2)try to build a dynamic flexible protection mechanism. From the case of Benson to Mayo then to Enfish, though the boundaries of this exception have remained elusive, courts at all levels in the US have never stop to the exploration and innovation. Unchanging mechanism can not help us to cope with challenges well due to the changing environment. The flexible protection mechanism emphasizing cooperation, systematism and integration is becoming prevalent.(3)take into consideration long-term economic, social and cultural factors. Courts at all levels in the US are always taking into account historical performance, political and economic factors, and it is important to pay close attention to the development and problems to harmoniously link up the policies between the monetary policy and fiscal policy, industrial policy and other macroeconomic policies.

\section{Conclusions}

Exploration of the consequences of patent protection for innovation in the software and business method is just beginning. Here, we have tried to suggest some of the pitfalls that existing patent policies. And in extending the full benefits of patent protection to business method, we must ensure that the unique characteristics do not result in an unprecedented and equally unique expansion of patent scope.We have recommended to improve the patent system and policy directed by realistic interests and based upon the current development in a flexible way.

\section{References}

\section{[1] Gottschalk v. Benson, 409 U.S. No.63 (1972).}

[2] B.Adam, Josh Lerner. Innovation and Its Discontents, NBER Innovation policy and the Economy. Vol. 6 (2006), p27-65.

[3] Diamond v. Chakrabarty, 447 U.S. 303, 309(1980).

[4] Diamond v. Diehr, 450 U.S. No. 79-1112. (1981).

[5] V. Richards., N. Hillis. Patentable Subject Matter: Software and Business Methods, Univ. of Tex. School of Law, 18th Annual Advanced Patent Law Institute, p.2 (Oct. 31, 2013).

[6] R. Allison., A. Lemley, and J. Walker. Patent Quality and Settlement among Repeat Patent Litigants. Georgetown Law Journal Vol 99, No. 3 (2011): p677-p712. 
[7] B. Lee, Supremes wrestle with business method, software patents, Ars Technica, https://

arstechnica.com/tech-policy/2009/11/supremes-wrestle-withbusiness-method-software-patents/.

[8] Mayo Collaborative Service v. Prometheus Laboratories Inc, 628 F.3d 1347, 97 USPQ 2d 1097 (Fed. Cir 2010)

[9] Information on http://www.autm.net/advocacy-topics/governmentissues/advocacy-public-policy/court-decisions/mayo-vprometheus/.Access time 2017-05-20.
[10] Ben D. Draft. Estimating the Impact of Alice v. CLS Bank Based on a Statistical Analysis of Patent Office Subject Matter Rejections.2016.

[11] Louis Ventre. Business Functions, Electronic Commerce and Financial Institution Date Processing. http://www.lventre.com/busmeth.html.

[12] Enfish LLC v. Microsoft Corporation, 2016 U.S. App. LEXIS 8699, (Fed. Cir. May 12, 2016).

[13] Information on http://www.huazhidawei.com/cn/about/news/423.html, 2016-1216. 